\title{
Clinical relevance of minimal residual disease monitoring in mature B- cell disorders: Role of qualitative and quantitative PCR-based strategies
}

\author{
Selina Sametti \\ Monica Astolfi \\ Luisa Giaccone \\ Irene Ricca \\ Marco Ladetto
}

\begin{abstract}
Although current treatments can induce clinically complete remissions in a high proportion of patients with mature B-cell disorders (MBCD), most of them actually relapse, because of the persistence of residual tumour cells which are undetectable using conventional diagnostic procedures. Qualitative polymerase-chain-reaction (PCR) based methods are increasingly used for minimal residual disease (MRD) detection, and provide useful prognostic information. In recent years these assays have been integrated by reliable quantitative PCR-approaches that are likely to further increase the prognostic impact of $M R D$ analysis in MBCD. In this review current approaches for qualitative and quantitative detection of MRD in MBCD are summarised. In addition, the prognostic aspects of molecular monitoring in the autologous and allogeneic transplantation setting are summarised. The experience accumulated over the past decade shows that PCR analysis has a prognostic impact in most MBCD especially when treated with high-dose regimens. Major advantages coming from the introduction of molecular monitoring in clinical programs have been: $i$ ) a rapid evaluation of the anti-tumour activity of innovative treatments; and ii) an early identification of patients with a bigh-risk of disease recurrence.

Rev.bras.hematol.hemoter, 2001, 23(1): 3-13
\end{abstract}

Key words: Minimal residual disease, mature B-cell disorders, lymphoproliferative disorders

\section{Introduction}

During the last 10 years, the treatment of mature B-cell disorders (MBCD) has dramatically changed $(1,2)$. Major advances in the field have been the introduction of high-dose chemotherapy regimens followed by autologous or allogeneic transplantation of hematopoietic cells (3-8), the development of novel drugs such as purine analogues (9) and monoclonal antibodies (10), the use of innovative methods for ex vivo manipulation of autologous stem cells (11-19) and most recently the introduction of tumour specific vaccination (20) strategies and cytokine modulators (21). Treatment evolution has been particularly remarkable in low-grade lymphomas, where palliative approaches have been progressively substituted by treatments aimed at disease eradication at least for patients younger than 60 years.

Divisione Universitaria di Ematologia - Azienda Ospedaliera S. Giovanni Battista Torino, Italy

\footnotetext{
Acknowledgements

We are grateful to the staff of Molecular Hematology Laboratory and in particular to Monica Astolfi, Ph.D. and Claudia Voena, Ph.D. This work was in part supported by AIRC (Associazione Italiana Ricerca sul Cancro), and CNR special project ACRO grant \# 96.00.742.PF39 to C. T.
}

Address correspondence to: Marco Ladetto $M D$ Cattedra di Ematologia. Via Genova 3, 10126 Torino, Italy Fax: (39) 11- 6963737

Phone: (39) 11- 6336507 ward; 6335329 office; 6336506 lab

E-mail: marco.ladetto@unito.it 
Despite the introduction of these new approaches, a sizeable fraction of patients achieving clinically complete remission actually relapse and die of their disease. The relapse is presumably caused by the persistence of small numbers of tumour cells that are below the limit of detection of standard diagnostic procedures. Therefore, considerable effort has been made over the past decade to develop new techniques that allow the detection of extremely small numbers of clonal cells. Among these techniques, the most sensitive and widely used is the polymerase-chain-reaction (PCR). Its use has been extensive in several haematological neoplasms, and the persistence of PCR detectable tumour cells has been correlated with increased likelihood of relapse in both myeloid and lymphoid neoplasms. In the MBCD setting, several studies have been published on the prognostic significance of minimal residual disease (MRD) detection. Most of these studies focus on indolent lymphomas (small lymphocytic lymphoma/chronic lymphocytic leukaemia [SLL/ $\mathrm{CLL}^{17,}{ }^{18}$, follicle centre lymphomas $[\mathrm{FCL}]^{22-24}$, mantle cell lymphomas [MCL] ${ }^{24,25}$ ) and multiple myeloma [MM] (26). This is mostly because these tumours are disseminated disorders with frequent microscopic or submicroscopic bone marrow (BM) and peripheral blood (PB) involvement, and thus they represent ideal targets for MRD evaluation with PCR-based assays (27, 28), compared to more localised diseases such as diffuse large cell lymphoma.

In this review, we summarise the characteristics of the most frequently used strategies for PCR detection of MRD in MBCD. Particular emphasis has been placed upon methodology and potential applications of the recently developed real-time quantitative PCR strategies. Finally, the prognostic impact of molecular monitoring in the ex vivo purging setting and after conventional or intensified therapy will be discussed.

\section{PCR strategies for monitoring residual disease in indolent lymphomas}

The essential requirement for a PCR assay is the presence of a tumour marker i.e. a DNA or RNA sequence that is constantly detectable in the neoplastic population and constantly undetectable in non-neoplastic cells. From these sequences primers (and in some cases probes) are designed to target genomic or complementary DNA sequences. These primers are then used for PCR amplification of either peripheral blood and/or bone marrow samples. There are two categories of tumour-specific molecular markers: tumour-specific translocations, and antigenreceptor rearrangements. Tumour translocations have several advantages: i) MRD detection is relatively simple since it involves only PCR amplification possibly followed by probe hybridisation; ii) they usually represent a stable molecular marker; iii) they are usually not detected in non-neoplastic cells. Their main disadvantage is that they can provide a molecular marker only for a subset of patients. Indeed FCL patients harbour the $\mathrm{t}(14 ; 18)$ translocation in approximately $60-80 \%$ of cases (22) while MCL patients have a PCR-amplifiable $\mathrm{t}(11 ; 14)$ translocation only in 30\% of cases (25). In addition, several other MBCD such as MM and SLL/CLL never harbour chromosomal translocations that can be routinely employed for MRD evaluation.

The rearrangement of immunoglobulin heavy-chain (IgH) has a wider applicability and can be used as a molecular marker in the vast majority of MBCD. However, their use for PCRdetection of MRD is somehow more complex than chromosomal translocations since it requires sequencing analysis of the rearranged variable regions in order to design tumourspecific primers and probes $(29,30)$.

Thus, the three most widely used clonal markers in MBCD are the $t(14 ; 18)$, the $t(11 ; 14)$ and the $\mathrm{IgH}$ gene rearrangement.

The $t(14 ; 18)$ is detectable in approximately $60-80 \%$ of FCL patients and in $30 \%$ of diffuse large cell lymphomas $(31,32)$. In the $\mathrm{t}(14 ; 18)$, the $\mathrm{Bcl}-2$ proto-oncogene on chromosome 18 is juxtaposed to the IgH locus on chromosome 14. Breakpoints are located at two main clusters 3' to the Bcl-2 coding region, named major breakpoint region (MBR) and minor cluster region $(\mathrm{mcr})(33,34)$, requiring two different sets of primers for PCR amplification. MRD evaluation is performed by PCR-amplification of the juctional region using a 5' primer derived from the Bcl-2 
locus and a 3' primer derived from the JH region of IgH genes. The most widely employed $\mathrm{Bcl}-2$ assays require reamplification of PCR products using a second set of internal primers followed by standard electrophoresis over agarose gels. These approaches named nested PCR are extremely sensitive (one lymphoma cell in $10^{5}-$ $10^{6}$ normal cells ${ }^{23,24}$ ) and do not involve hybridisation to a radioactive probe as required in other Bcl-2 assays.

The $t(11 ; 14)$ fuses the Bcl-1 locus with the IgH locus and occurs in the vast majority of MCL patients (70-100\%) (25, 35). Breakpoints on chromosome 11 have been found dispersed over more than $100 \mathrm{~Kb}$ of genomic DNA. Three clusters have been identified so far; the most important is named major translocation cluster (MTC) and contains approximately $30-50 \%$ of these translocations. This small DNA region represents a suitable target for PCR amplification. PCR detection of the $t(11 ; 14)$ is usually performed employing semi-nested PCR: two consecutive amplifications are performed, using the same 3' primer derived from the $\mathrm{JH}$ region and two 5' primers derived from the major translocation cluster of the Bcl-1 locus. This approach can usually detect one lymphoma cell out of $10^{5}$ normal cells (25).

The IgH gene rearrangement has been used in different subtypes of MBCD, including SLL/ CLL, FCL, MCL and MM (17, 18, 25, 29, 30). This method relies on the amplification and sequencing of the $\operatorname{IgH}$ rearranged variable region (VDJ). VDJ amplification is performed using consensus 5' primers derived from VDJ portions which are highly homologous among different $\mathrm{V}$ genes, and 3' primers derived from the final portion of the $\mathrm{JH}$ region which is remarkably homologous among the $6 \mathrm{JH}$ genes. PCR amplification of the tumour-specific VDJ should be performed on samples containing at least a tumour infiltration of 5-10\%. Amplified VDJs are then sequenced to identify the three complementarily-determining regions (CDRs). These regions code for the antigen-binding site and are unique to each B-cell clone. From the CDR2 and CDR3, oligonucleotide primers and probes are usually designed, which are then employed on remission samples for minimal residual disease monitoring. This method can provide a tumour marker in approximately $80 \%$ of lymphoma and myeloma patients. PCR analysis using the $\mathrm{IgH}$ rearrangement has specificity and sensitivity similar to translocationbased assays (30), although sensitivity may display significant variation depending on the performances of the chosen primer pair.

The main limitation of standard PCR analysis is its intrinsic qualitative nature. Although qualitative analysis has been extremely useful in several clinical settings, the development of accurate and reproducible methods for quantitative analysis of MRD is required. Traditional quantitative or semiquantitative approaches to PCR analysis have shown limited applicability due to high complexity and lack of reproducibility. Recently the development of the TaqMan chemistry and analytical thermal cyclers has allowed the development of effective, accurate and reproducible approaches for quantitative analysis of minimal residual disease in B-cell disorders which are usually defined as real time PCR. These methods are highly accurate mostly because they allow direct measurement of quantitative data at the beginning of the exponential phase of PCR amplification and thus eliminate biases taking place during late postexponential phases of the reaction and during post-PCR manipulation of samples (36). In the last two years effective approaches have been designed for real time PCR in MBCD using both tumor-specific translocations (37-39) and the IgH rearrangement $(40,41)$ and a clear indication of usefulness of these strategies to predict the outcome of ex-vivo purging strategies has recently been provided (42). However a more extensive use of these strategies still has to be performed in order to clearly define in which additional settings they might provide useful prognostic information.

\section{Molecular analysis as a tool to assess the efficacy of in vitro purging procedures}

High-dose chemotherapy regimens followed by autologous transplantation with BM or peripheral blood progenitor cells (PBPC) are increasingly used for the treatment of MBCD 
(3, 4, 6-8). However, since many of these neoplasms such as CLL, FCL and MM have a high degree of $\mathrm{PB}$ and $\mathrm{BM}$ involvement, stem cell grafts frequently display persistence of occult tumour cells that can contribute to disease relapse (43). Efforts have been devoted to reduce the tumour load of stem cell grafts either by ex vivo manipulation of stem cell harvests (ex-vivo purging) or alternatively through the administration of drugs capable of depleting tumour cells from bone marrow or peripheral blood prior to stem cell harvesting (ex-vivo purging). In vitro purging of stem cell grafts has been regarded as a potentially useful method to obtain a significant reduction and possibly the eradication of contaminating tumour cells. PCR analysis has been extensively used in this setting: the efficacy of purging procedures in different diseases has been evaluated giving the percentage of patients in which grafts were successfully cleared of residual lymphoma cells. In addition, correlations between infusion of PCR-negative grafts and disease-free-survival, have been investigated $(22,24,28)$.

Investigators from Dana Farber Cancer Institute - Boston, have pioneered large-scale ex-vivo purging techniques using anti B-cell monoclonal antibodies together with complement-mediated lysis. This strategy has been employed in SLL/CLL, FCL and MCL (18, $27,28)$. These investigators observed significant differences among different subtypes: in FCL, BM harvests are cleared of PCR-detectable disease in approximately $50 \%$ of patients, and the reinfusion of a PCR-negative graft was correlated with a better disease-free survival (27). A similar finding has been observed on a panel of $21 \mathrm{SLL} / \mathrm{CLL}$ patients. However, more recent data on a larger panel of SLL/CLL patients seem to provide less optimistic results with more than $75 \%$ of patients still harbouring residual tumour cells despite ex-vivo purging (44). The same purging procedure has been applied to MCL patients, giving dismal results. Marrow grafts were virtually always PCR-positive despite exvivo manipulation (25).

Less experience has been accumulated on molecular results following ex-vivo manipulation of PBPC. Tarella et al. (19) have employed immunomagnetic purging with negative selection in both FCL and MCL patients. Results were remarkably similar to those observed using ex vivo purged BM harvests, with $100 \%$ of MCL patients remaining PCRpositive and approximately $40 \%$ of harvests from FCL patients successfully cleared of PCRdetectable disease and achieving long term clinical and molecular remission.

Until recently, it was unexplained why only a proportion of FCL patients can be cleared of PCR-detectable disease, by ex-vivo manipulation. This discrepancy might be related to a different tumour burden but alternative explanations can also be postulated such as an intrinsic resistance of tumour cells to selection procedures or a lack of reproducibility of the purging method. Real time quantitative PCR has allowed clarifying this issue at least for patients treated with immunomagnetic purging. Indeed we have recently published that a strong correlation exists between low tumour burden and successful ex-vivo purging using the MaxSep Separator (42). This suggests that a successful debulkying prior to ex-vivo manipulation is of great importance to achieve optimal results using ex vivo purging.

Although most purging studies in NHL were performed using negative selection, other purging techniques have been recently developed. Positive selection of CD34+ cells has recently gained a considerable interest. Some studies have shown that CD34+ selection was successful in eradicating residual lymphoma cells from both PBPC and BM grafts in FCL patients $(14,45)$. In contrast CD34+ selection was largely unsuccessful in SLL/CLL patients (17).

In MM patients CD34+ selection has been generally preferred to negative selection approaches, mostly due to the lack of a panel of antibodies that specifically target malignant plasma cells. Although several different procedures proved feasible in terms of hematopoietic recovery, results were less encouraging in terms of clearance of minimal residual disease. Several reports have demonstrated a significant reduction of plasma cell contamination assessed by flow cytometry for the CD38 antigen. However, the value of this antigen as a marker of tumour plasma cells is still a matter of debate, since two studies based 
on quantitative PCR have demonstrated that the vast majority of plasma cells in stem cell harvests are not related to the tumour clone (46-47).

Several other studies (48-50) have addressed the impact of CD34+ selection by PCR performed with tumour specific primers. Most of these studies have shown that plasma cell contamination in stem harvests is extremely difficult to eradicate using ex-vivo manipulation. However, intensified chemotherapeutic debulkying did not allow the collection of PCR negative harvests in these neoplasms also (47).

In conclusion, although purging procedures are extremely attractive approaches, that seem to be successful at least in FCL, they still need to be considerably improved in order to became a valuable tool for the great bulk of patients with MBCD. PCR analysis and particularly real time PCR will probably represent the optimal tool to help investigators in their search for more effective and reproducible approaches to stem cell selection.

\section{Role of molecular monitoring in the prediction of relapse following conventional and high-dose chemotherapy treatments}

An important application of MRD assays is the molecular monitoring of patients achieving complete remission. The term "complete remission" is used to define complete disappearance of any sign of disease by means of standard laboratory and clinical procedures. This condition encompasses different clinical situations including eradication of the neoplastic population, long-term persistence of tumour cells with no tendency to relapse, and presence of residual tumour cells able to rise to an overt relapse during the subsequent follow-up period. Conventional diagnostic approaches are unable to distinguish between these situations. Sequential analysis of MRD has provided novel insights on the behaviour of residual tumour cells allowing the identification of different prognostic subgroups. The studies with the longest observation period have been performed in FCL patients undergoing autologous transplantation with purged BM cells (22). Serial PCR analysis has shown that patients with persistent molecular remission had very low if any chances of relapse. On the other hand patients with persistent PCR positivity experienced an extremely high incidence of relapse. Finally patients with intermittently PCRpositive and PCR-negative results showed an intermediate probability of disease recurrence.

A similar correlation between molecular monitoring and disease-free survival has been also observed in patients undergoing high-dose chemotherapy followed by autografting of unmanipulated PBPC. We have shown that patient harvesting PCR-negative BM and/or PBPC grafts, displayed persistent PCR-negativity following autologous transplantation. Among these patients none have relapsed, while disease recurrences were frequently observed among patients with persistent PCR-positivity (24). Similar results in terms of correlation between PCR-positivity and high incidence of relapse were also observed by Hardigham et al. (51) and Moos et al. (52). Most of these results were based on single Centre Trials and thus lacked confirmation at the multicentre level. The Gruppo Italiano Trapianto di Midollo Osseo (GITMO) has recently completed a multicentre trial involving 20 Italian BMT Units. Centralised PCR analysis has been performed, and evidence for a high prognostic value of PCR analysis both on stem cell harvests and following autologous transplantation has been confirmed.

A recent report from the MD Anderson Cancer Center - Houston related a high rate of molecular remissions after conventional dose chemotherapy (66\%). They could demonstrate a correlation between molecular response during the first year of therapy and failure-free survival (53). It is somehow difficult to compare these results with those obtained after purged or unpurged autografting. In the MD Anderson study, the achievement of molecular response, was to a certain extent independent of the clinical response: one third of patients in CR became PCR-negative and one third of patients in partial remission became PCR-negative as well. In contrast, the data from autografting studies derive from CR patients only. Although these findings are important we believe that a more extensive evaluation of the prognostic impact of MRD in the non-transplantation setting 
should be performed in order to put these data into the most correct perspective.

Recently Czuczman et al. have opened a novel field of investigation: they have shown that conventional chemotherapy in combination with anti-CD20 chimeric antibody is able to produce durable clinical and molecular remissions (54). A careful long-term monitoring is required to ascertain the clinical relevance of molecular data in this setting. In addition, Magni et al. have recently shown that Rituximab supplementation can dramatically improve the molecular results obtained with high-dose sequential chemotherapy in FCLand also in MCL where molecular remissions were achieved only exceptionally in the pre-Rituximab age (55).

Molecular monitoring has been also performed in MCL and SLL/CLL patients. These studies, however, have involved a smaller panel of patients. In SLL/CLL, Gribben et al. showed a pattern similar to that observed in FCL, but with less satisfactory results (18). Molecular followup data from SLL/CLL patients undergoing highdose chemotherapy followed by autografting of unmanipulated PBPC were quite disappointing. Although clinically complete remissions were frequently achieved, the persistence of PCRpositivity after transplantation represented a nearly constant finding (56).

Multiple myeloma is still considered as an incurable disease despite significant improvement in disease survival has been obtained with autologous transplantation (57). Molecular studies fully confirm this point of view (58). One single report has shown that a small fraction of patients can actually achieve molecular remissions (59). This subgroup of patients seems to have better disease-free survival, suggesting that heavy cytoreduction is useful also for MM patients. The greatest hope for a curative therapeutic modality in $\mathrm{MM}$ arises from allogeneic transplantation. Several studies have shown that molecular remissions can be achieved following allogeneic transplantation (58). Unfortunately this procedure is suitable only for a minority of MM patients, due to the high age of incidence of this disease. Considerable expectation relies upon the novel allo-grafting procedures with reduced conditioning intensity that may widen the clinical indication of allogeneic transplantation in the MM field (60).

\section{Conclusion and future perspectives}

The treatment of MBCD is a rapidly evolving field and novel treatments are constantly under evaluation. However, the prolonged natural history of these neoplasms is a potential obstacle to the rapid development of innovative therapeutic strategies since several years are usually required in order to draw definitive clinical conclusions on a given treatment. In recent years, considerable experience has been accumulated on PCR-based evaluation of MRD, and the correlation between PCR status and disease-free survival is now consolidated at least in the transplantation setting. Since PCR analysis can rapidly provide indications about the effectiveness of innovative treatments, the introduction of "molecular end-points" in clinical studies should be strongly encouraged in order to warrant a rapid evaluation of novel therapeutic strategies. Another potentially important application of molecular analysis is the early treatment of patients who show persistence (or increase, if quantitative approaches are used) of molecularly detectable diseases, and thus are at high-risk of relapse. These patients are ideal candidates for innovative treatments due to their poor short-term prognosis associated with low tumour burden that is probably critical for a successful treatment with novel drugs and/or immunotherapy.

The impact of PCR analysis in the management of MBCD has been strong, and therapeutic evolution in this field has been greatly supported by data obtained from molecular studies. However, it should be stressed that the value of PCR-negativity will change after the introduction of monoclonal antibodies and potentially also following other novel treatments such as idiotype vaccination since new treatments might be more effective in $\mathrm{BM}$ and $\mathrm{PB}$ compared to other disease sites such as lymph nodes. Novel studies are awaited to validate the prognostic value of PCR analysis in these novel therapeutic settings. It cannot be excluded that PCR analysis will require to be partially readapted in order to address these future issues. 


\section{Monitorização e relevância clínica da doença residual mínima nas síndromes linfoproliferativas de células B-maduras}

Selina Sametti, Monica Astolfi, Luisa Giaccone, Irene Ricca, Marco Ladetto

\section{Resumo}

Os tratamentos atuais induzem remissão clínica completa em uma alta percentagem de pacientes portadores de Sindromes linfoproliferativas de células B maduras (SLBM). No entanto, muitos destes pacientes recaem devido a persistência de células tumorais residuais que são indetectáveis pelos métodos de diagnóstico convencionais. Os métodos baseados na reação em cadeia da polimerase (PCR) qualitativos cada vez mais têm sido utilizados para a detecção da doença residual minima (DRM) epropiciam informações úteis em relação ao prognóstico dos pacientes.

Neste relato as condutas atuais em relação a DRMe o emprego dos métodos de PCR qualitativos e quantitativos são apresentadas e discutida a importância da monitorização da DRM para os transplantes autólogos e alogênicos de medula óssea. A experiência acumulada nas últimas décadas demonstra que as análises de PCR têm um impacto no prognóstico da maioria das SLBM, especialmente nos pacientes submetidos a programas com altas doses de quimioterapia. As principais vantagens da monitorização molecular são: rapidez na avaliação da atividade anti-tumoral dos novos tratamentos e identificação precoce dos pacientes que apresentem alto risco de recaida de moléstia. Rev.bras.hematol.hemoter., 2001, 23(1): 3-13

Palavras-chave: Doença residual minima, doenças linfoproliferativas de células $B$, Sindromes linfoproliferativos

\section{References}

1. Armitage JO. Bone marrow transplantation for indolent lymphomas. Seminars in Oncology 1993; 20:136-42.

2. Coiffier B. Towards a cure in indolent lymphoproliferative diseases? Eur J Cancer 1995; 31A: 2135-7.

3. Coiffier B, Philip T, Burnett AK, Symann
ML. Consensus Conference on Intensive Chemotherapy Plus Hematopoietic StemCell Transplantation in Malignancies: Lyon, France, June 4-6, 1993. J Clin Oncol. 1994; 12: 226-31.

4. Freedman AS, Gribben JG, Neuberg D, Mauch P, Soiffer RJ, Anderson KC, Pandite L, Robertson MJ, Kroon N, Ritz J, Nadler LM. High-dose therapy and autologous bone marrow transplantation in patients with follicular lymphoma during first remission. Blood 1996; 88: 2780-6.

5. Gianni AM, Bregni M, Siena S, Brambilla C, Di Nicola M, Lombardi F, Gandola L, Tarella C, Pileri A, Ravagnani F, Valagussa P, Bonadonna G. High-dose chemotherapy and autologous bone marrow transplantation compared with MACOP-B in aggressive B-cell lymphoma. N Engl J Med 1997; 336:1290-7.

6. Philip T, Guglielmi C, Hagenbeek A, Somers $\mathrm{R}$, Van der Lelie H, Bron D, Sonneveld P, Gisselbrecht C, Cahn JY, Harousseau JL. Autologous bone marrow transplantation as compared with salvage chemotherapy in relapses of chemotherapy-sensitive nonHodgkin's lymphoma. N Eng J Med 1995; 333:1540-5.

7. Bastion Y, Brice P, Haioun C, Sonet A, Salles G, Marolleau JP, Espinouse D, Reyes F, Gisselbrecht C, Coiffier B. Intensive therapy with peripheral blood progenitor cell transplantation in 60 patients with poorprognosis follicular lymphoma. Blood 1995; 86: 3257-62.

8. Bierman PJ, Vose JM, Anderson JR, Bishop MR, Kessinger A, Armitage JO. High-dose therapy with autologous hematopoietic rescue for follicular low-grade non-Hodgkin's lymphoma. J Clin Oncol 1997; 15: 445-50.

9. Wright SJ, Robertson LE, O'Brien S, Plunkett $\mathrm{W}$, Keating MJ. The role of fludarabine in bematological malignancies. Blood 1994; 8:125-34.

10. Leget G, Czuczman MS. Use of rituximab, the new FDA-approved antibody. Curr Opin Oncol 1998; 10:548-51.

11. Bensinger WI. Should we purge? Bone Marrow Transplantation 1998; 21:113-5.

12. Gee A. Purging of peripheral blood stem cell grafts. Stem Cells 1995; 13:52-62. 
13. Gorin NC, Lopez M, Laporte JP, Quittet P, Lesage $\mathrm{S}$, Lemoine $\mathrm{F}$, Berenson RJ, Isnard F, Grande M, Stachowiak J. Preparation and successful engraftment of purified CD34+ bone marrow progenitor cells in patients with non-Hodgkin's lymphoma. Blood 1995; 85:1647-54.

14. Lopez M, Lemoine F, Firat H, Fouillard L, Laporte JP, Lesage S, Isnard F, Stachowiak J, Ferrer-Le Coeur F, Morel P, Najman A, Douay L, Gorin NC. Bone marrow versus peripheral blood progenitor cells CD34 selection in patients with non-Hodgkin's lymphomas: different levels of tumor cell reduction. Implications for autografting. Blood 1997; 90: 2830-8.

15. Lowenberg B, Voogt P. Autologous stem-cell transplantation and purging [editorial]. $\mathbf{J}$ Clin Oncol 1996; 14: 2194-6.

16. Gribben JG. Attainment of molecular remission: a worthwhile goal. J Clin Oncol 1994; 12: 1532-4.

17. Scime R, Indovina A, Santoro A, Musso M, Olivieri A, Tringali S, Crescimanno A, Montanari M, Felice R, Catania P, Mariani G, Leoni P, Majolino I. PBSC mobilization, collection and positive selection in patients with chronic lymphocytic leukemia. Bone Marrow Transplantation 1998; 22: 1159-65.

18. Provan D, Bartlett-Pandite L, Zwicky C, Neuberg D, Maddocks A, Corradini P, Soiffer R, Ritz J, Nadler LM, Gribben JG. Eradication of polymerase chain reactiondetectable chronic lymphocytic leukemia cells is associated with improved outcome after bone marrow transplantation. Blood 1996; 88: 2228-35.

19. Tarella C, Corradini P, Astolfi M, Bondesan P, Caracciolo D, Cherasco C, Ladetto M, Giaretta F, Ricca I, Vitolo U, Pileri A, Ferrero D. Negative immunomagnetic ex vivo purging combined with bigh-dose chemotherapy with peripheral blood progenitor cell autograft in follicular lymphoma patients: evidence for long-term clinical and molecular remissions. Leukemia. 1999; 13(9):1456-62.

20. Bendandi M, Gocke CD, Kobrin CB, Benko FA, ternas LA, Pennington R, Watson TM, Reynolds CW, Gause BL, Duffley PL, Jaffe
ES, Creekmore SP, Longo DL, Kwak LW. Complete molecular remissions induced by patient-specific vaccination plus granulocytemonocyte colony-stimulating factor against lymphoma. Nat Med 1999; 5: 1171-7.

21. Hideshima T, Chauhan D, Shima Y, Raje N, Davies FE, Tai YT, Treon SP, Lin B, Schlossman RL, Richardson P, Muller G, Stirling DI, Anderson KC. Thalidomide and its analogs overcome drug resistence of buman multiple myeloma cells to conventional therapy. Blood 2000; 96(9):2943-50.

22. Gribben JG, Neuberg D, Freedman AS, et al. Detection by polymerase chain reaction of residual cells with the bcl-2 translocation is associated with increased risk of relapse after autologous bone marrow transplantation for B-cell lymphoma. Blood 1993; 81:3449-57.

23. Pappa V, Wilkes S, Salam A, Young B, Lister $\mathrm{T}$, Rohatiner A. Use of the polymerase chain reaction and direct sequencing analysis to detect cells with the $t(14 ; 18)$ in autologous bone marrow from patients with follicular lymphoma, before and after in vitro treatment. Bone Marrow Transplantation 1998; 22:553-8.

24. Corradini P, Astolfi M, Cherasco C, Ladetto M, Voena C, Caracciolo D, Pileri A, Tarella C. Molecular monitoring of minimal residual disease in follicular and mantle cell nonHodgkin's lymphomas treated with high-dose chemotherapy and peripheral blood progenitor cell autografting. Blood 1997; 89:724-31.

25. Andersen NS, Donovan JW, Borus JS, Poor CM, Neuberg D, Aster JC, Nadler LM, Freedman AS, Gribben JG. Failure of immunologic purging in mantle cell lymphoma assessed by polymerase chain reaction detection of minimal residual disease. Blood 1997; 90: 4212-21.

26. Cavo M, Terragna C, Martinelli G, Ronconi S, Zamagni E, Tosi P, Lemoli RM, Benni M, Pagliani G, Bandini G, Tura S. Molecular monitoring of minimal residual disease in patients in long-term complete remission after allogeneic stem cell transplantation for multiple myeloma. Blood 2000; 96(1):355-7. 
27. Berinstein NL, Reis MD, Ngan BY, Sawka C, Jamal HH, Kuzniar B. Detection of occult lymphoma in the peripheral blood and bone marrow of patients with untreated early-stage and advanced-stage follicular lymphoma. $\mathbf{J}$ Clin Oncol 1993; 11: 1344-52.

28. Gribben JG, Freedman AS, Neuberg D, Roy DC, Blake KW, Woo SD, Grossbard ML, Rabinowe SN, Coral F, Freeman GJ. Immunologic purging of marrow assessed by PCR before autologous bone marrow transplantation for B-cell lymphoma. N Eng J Med 1991; 325: 1525-33.

29. Corradini P, Voena C, Astolfi M, Ladetto M, Tarella C, Boccadoro M, Pileri A. High-dose sequential chemoradiotherapy in multiple myeloma: residual tumor cells are detectable in bone marrow and peripheral blood cell harvests and after autografting. Blood 1995; 85:1596-602.

30. Voena C, Ladetto M, Astolfi M, Provan D, Gribben JG, Boccadoro,M, Pileri A, Corradini P. A novel nested-PCR strategy for the detection of rearranged immunoglobulin heavy-chain genes in $B$ cell tumors. Leukemia 1997; 11:1793-8.

31. Lee MS, Chang KS, Cabanillas F, Freireich E, Trujillo J, Stass SA. Detection of minimal residual cells carrying the $1(14 ; 18)$ by DNA sequence amplification. Science 1999; 237:175-8.

32. Bakhshi A, Jensen JP, Goldman P, Wright JJ, McBride OW, Epstein AL, Korsmeyer SJ. Cloning the chromosomal breakpoint of t $14 ; 18)$ buman lymphomas: clustering around $J H$ on chromosome 14 and near a transcriptional unit on 18. Cell 1985; 41: 899-906.

33. Cleary ML, Galili N, Sklar J. Detection of a second $t(14 ; 18)$ breakpoint cluster region in buman follicular lymphomas. J Exp Med 1986; 164:315-20.

34. Cleary ML, Sklar J. Nucleotide sequence of a t(14;18) chromosomal breakpoint in follicular lymphoma and demonstration of $a$ breakpoint-cluster region near a transcriptionally active locus on chromosome 18. Proc Natl Acad Sci USA 1985; 82: 7439-43.

35. Tsujimoto Y, Yunis J, Onorato-Showe L, Erikson J, Nowell PC, Croce CM. Molecular cloning of the chromosomal breakpoint of $B$ - cell lymphomas and leukemias with the $t(11 ; 14)$ chromosome translocation. Science 1984; 224: 1403-6.

36. Orlando C, Pinzani P, Pazzagli M. Developments in quantitative PCR. Clin Chem Lab Med 1998; 36: 255-69.

37. Luthra R, McBride JA, Cabanillas F, Sarris A. Novel 5, exonuclease-based real-time PCR assay for the detection of $t(14 ; 18)(q 32 ; q 21)$ in patients with follicular lymphoma. Am J Pathol 1998; 153:63-8.

38. Dolken L, Schuler F, Dolken G. Quantitative detection of $t$ (14;18)-positive cells by real-time quantitative PCR using fluorogenic probes. Biotechniques. 1998 Dec; 25(6): 1058-64.

39. Olsson K, Gerard CJ, Zehnder J, Jones C, Ramanathan R, Reading C, Hanania EG. Real-time t(11;14) and t 14 ; 18) PCR assays provide sensitive and quantitative assessments of minimal residual disease (MRD). Leukemia. 1999; 13(11): 1833-42.

40. Gerard CJ, Olsson K, Ramanatham R, Reading C, Hanania EG. Improved quantitation of minimal residual disease in multiple myeloma using real-time polymerase chain reaction and plasmid-DNA complementarity determining region III standards. Cancer Res 1998; 58:3957-64.

41. Ladetto M, Donovan JW, Schlossman R, Anderson KC, Gribben JG. Limitations of quantitative detection of immunoglobulin beavy chain (IgH) gene rearrangements in multiple myeloma (MM) patients using realtime PCR. Blood 1998; 92:286a.

42. Ladetto M, Sametti S, Donovan JW, Ferrrero D, Astolfi M, Mitterer M, Ricca I, Drandi D, Corradini P, Coser P, Pileri A, Gribben JG, Tarella C. A validated real-time quantitative PCR approach shows a correlation between tumor burden and successful ex vivo purging in follicular lymphoma patients. Exp Hem 2001 (in press).

43. Brenner MK, Rill DR, Holladay MS, Heslop HE, Moen RC, Buschle M, Krance RA, Santana VM, Anderson WF, Ihle JN. Gene marking to trace origin of relapse after autologous bone marrow transplantation. Lancet 1993; 341:85-90.

44. Donovan JW, Andersen NS, Poor CM, Bowers D, Gribben JG. Prospective analysis 
of minimal residual disease detection in patients with CLL undergoing autologous and allogeneic BMT. Blood 1998; 92:652a.

45. Di Nicola M, Siena S, Corradini P, Bregni M, Ruffini PA, Milanesi M, Tarella C, Gianni AM. Elimination of bcl-2-IgH positive follicular lymphoma cells from blood transplants with high recovery of hematopoietic progenitors by the Milteny CD34+ cell sorting system. Bone Marrow Transplantation 1996; 18:1117.

46. Vescio RA, Han EJ, Schiller GJ, Lee JC, Wu CH, Cao J, Shin J, Kim A, Lichtenstein AK, Berenson JR. Quantitative comparison of multiple myeloma tumor contamination in bone marrow harvest and leukapheresis autografts. Bone Marrow Transplant. 1996; 18(1): 103-10.

47. Ladetto M, Omedè P, Sametti S, Donovan JW, Astolfi M, Giaccone L, Giaretta F, Volpato F, Bringhen S, Palumbo A, Bruno B, Pileri A, Gribben JG, Boccadoro M. Real time quantitative PCR shows that peripheral blood stem cell (PBPC) harvests are significantly less contaminated than bone marrow (BM) in multiple myeloma patients (MM). ASH 2000 (abstract).

48. Vescio R, Schiller G, Stewart AK, Ballester O, Noga S, Rugo H, Freytes C, Stadtmauer E, Tarantolo S, Sahebi F, Stiff P, Meharchard J, Schlossman R, Brown R, Tully H, Benyunes $\mathrm{M}$, Jacobs C, Berenson R, DiPersio J, Anderson K, Berenson J. Multicenter phase III trial to evaluate CD34(+) selected versus unselected autologous peripheral blood progenitor cell transplantation in multiple myeloma. Blood 1999 15; 93(6): 1858-68.

49. Martinelli G, Terragna C, Lemoli RM, Cavo M, Benni M, Motta MR, Amabile M, Ottaviani E, Testoni N, de Vivo A, Tura S. Clinical and molecular follow-up by amplification of the CDR-III IgH region in multiple myeloma patients after autologous transplantation of bematopoietic CD34+ stem cells.

Haematologica 1999; 84:397-404.

50. Willems P, Croockewit A, Raymakers R, Holdrinet R, van Der Bosch G, Huys E, Mensink E. CD34 selections from myeloma peripheral blood cell autografts contain residual tumour cells due to impurity, not to CD34+ myeloma cells. Br J Haematol. 1996; 93(3): 613-22.
51. Hardingham JE, Kotasek D, Sage RE, Gooley LT, Mi JX, Dobrovic A, Norman JE, Bolton AE. Significance of molecular marker-positive cells after autologous peripheral-blood stemcell transplantation for non-Hodgkin's lymphoma. J Clin Oncol 1995; 13: 1073-9.

52. Moos M, Schulz R, Martin S, Haas R. The remission status before and the PCR status after bigh-dose therapy with peripheral blood stem cell support are prognostic factors for relapse-free survival in patients with follicular non-Hodgkin's lymphoma.

Leukemia 1998; 12: 1971.

53. Lopez-Guillermo A, Cabanillas F, McLaughlin $\mathrm{P}$, Smith T, Hagemeister FB, Rodriguez MA, Romaguera MA, Sarris A, Pugh WC, Lee MS. The clinical significance of molecular response in indolent follicular lymphomas. Blood 1998; 91: 2955-60.

54. Czuczman MS, Grillo-Lopez AJ, White CA, Saleh M, Gordon L, LoBuglio AF, Jonas C, Klippenstein D, Dallaire B, Varns C. Treatment of patients with low-grade Bcell lymphoma with the combination of chimeric anti-CD20 monoclonal antibody and CHOP chemotherapy. J Clin Oncol 1999; 17:268.

55. Magni M, Di Nicola M, Devizzi L, Matteucci P, Lombardi F, Gandola L, Ravagnani F, Giardini R, Dastoli G, Tarella C, Pileri A, Bonadonna G, Gianni AM. Successful in vivo purging of CD34containing peripheral blood harvests in mantle cell and indolent lymphoma: evidence for a role of both chemotherapy and rituximab infusion. Blood 2000; 96(3):864-9.

56. Corradini P, Astolfi M, Voena C, Caracciolo D, Vitolo U, Benedetti G, Pileri A, Tarella C. High-dose chemotherapy and $P B P C$ autografting inducedurable molecular remissions in follicular lymphomas but not in small lymphocytic and mantle cell lymphomas. Blood 1999; 92:463a.

57. Attal M, Harousseau JL. Autologous peripheral blood progenitor cell transplantation for multiple myeloma.

Baillieres Best Pract Res Clin Haematol. 1999; 12(1):171-191. 
58. Corradini P, Voena C, Tarella C, Astolfi M, Ladetto M, Palumbo A, Van Lint MT, Bacigalupo A, Santoro A, Musso M, Majolino I, Boccadoro M, Pileri A. Molecular and clinical remissions in multiple myeloma: role of autologous and allogeneic transplantation of hematopoietic cells. J Clin Oncol. 1999; 17(1): 208-15.

59. Martinelli G, Terragna C, Zamagni E, Ronconi S, Tosi P, Lemoli RM, Bandini G, Motta MR, Testoni N, Amabile M, Ottaviani E, Vianelli N, de Vivo A, Gozzetti A, Tura S, Cavo M. Molecular remission after allogeneic or autologous transplantation of hematopoietic stem cells for multiple myeloma. J Clin Oncol. 2000; 18(11): 2273-81.

60. Molina A, Sahebi DG, Maloney BM, Sandmaier P, McSweeney A, Kashyap W, Besinger T, Chauncey FR, Appelbaum SJ, Forman R. Nonmyeloablative peripheral blood stem cell (PBPC) allografts following cytoreductive autotransplants for treatment of multiple myeloma (MM). ASH 2000 (abstract).

Recebido : 09/02/01

Aceito : 14/03/01 